\title{
Hepatitis B Virus Core Antibody
}

National Cancer Institute

\section{Source}

National Cancer Institute. Hepatitis B Virus Core Antibody. NCI Thesaurus. Code C62797.

An antibody produced by $B$ lymphocytes to the hepatitis B core antigen as part of the immune response to hepatitis B viral infection. 